\title{
Antihyperlipidemia Effects of Jengkol Leaf Extract (Archidendron jiringa)
}

\author{
$1^{\text {st }}$ Ade Arinia Rasyad \\ Department of Pharmacy \\ STIFI Bhakti Pertiwi Palembang \\ Palembang, Indonesia \\ Email: adearinia74@gmail.com
}

\author{
$2^{\text {nd }}$ Ensiwi Munarsih \\ Department of Pharsmacy \\ STIFI Bhakti Pertiwi Palembang \\ Palembang, Indonesia \\ Email: ensiwi.munarsih@gmail.com
}

\author{
$3^{\text {rd }}$ Fadilah Safitri \\ Department of Pharmacy \\ STIFI Bhakti Pertiwi Palembang \\ Palembang, Indonesia \\ Email: fadilahsafitri628@gmail.com
}

Corresponding author: ensiwi.munarsih@gmail.com

\begin{abstract}
This Jengkol is one of the native plants in Indonesia. Jengkol beans are known as a popular food ingredient, and empirically the leaf is also used by people to treat hyperlipidemia. This study aimed to determine the antihyperlipidemic effect of Jengkol leaf extract (Achidendron jiringa) on male white rats induced by propylthiouracil and High fat diet. This was an experimental research with complete random design. Animals were divided into 5 groups: negative control group (tween 80), positive control (simvastatin $10 \mathrm{mg} / \mathrm{kg}$ BW), 3 other groups were given Jengkol leaf extract a dose of 100,200 , and $400 \mathrm{mg} / \mathrm{kg} \mathrm{BW}$. The result showed that there is a significant decline in total cholesterol levels after being given Jengkol leaf extract for 14 days at each dose respectively compared to the hyperlipidemic group. The percentages were $41.45 \%, 47.76 \%, 44.91 \%$, and the simvastatin group was $56.70 \%$. The study also revealed the optimal dose of Jengkol leaf extract that was $200 \mathrm{mg} / \mathrm{kg} \mathrm{BW}$
\end{abstract}

Keywords: Jengkol leaves, Archidendron jiringa, antihyperlipidemia, propylthiouracil.

\section{INTRODUCTION}

Hyperlipidemia is a condition characterized by an increase of total cholesterol levels in the blood, as well as an increase of Low-Density Lipoprotein (LDL) and accompanied by a decrease of High-Density Lipoprotein (HDL) in the blood. Excess amount of cholesterol from the normal limit causes an increased risk of coronary heart disease and atherosclerosis. It is caused by the narrowing of the arteries, which causes interference in the blood flow to the heart [1], [2].
According to the World Health Organization (WHO) 2015, hyperlipidemia was the most significant factor causing cardiovascular diseases such as stroke and coronary heart disease (CHD), while the death reached 2.6 million ( $4.5 \%$ of total deaths) and 29.7 million experienced the inability to live everyday life [3]. The highest prevalence of hyperlipidemia was more common in urban than in rural areas, significantly more in women than in men [4]. One of the drugs that could reduce blood cholesterol levels was a group of inhibitors of HMG CoA reductase (statins) and their derivatives, they were quite effective in reducing blood cholesterol and LDL. Simvastatin is a derivative of HMG CoA reductase (statin) inhibitors and one of the cholesterol-lowering drugs commonly used by patient. However, the use of simvastatin also had side effects such as neurology, tremors, dizziness, vertigo, memory loss, accelerating cataracts, and hypertension [5]. Another alternative that could be done to reduce cholesterol levels was to do the appropriate type of physical exercise, to take a healthy diet, or to consume herbs that could reduce blood cholesterol levels [6].

As stated by Harosid (2012) that Jengkol leaf contained alkaloids, flavonoids, tannins, glycosides, saponins, steroids, and triterpenoids. Whereas based on the results of phytochemical screening conducted by Yunitasari et al, (2016) Jengkol leaf contained alkaloids, flavonoids, saponins, steroids, triterpenoids, tannins, polyphenols, monoterpenes, sesquiterpenes, and quinones [7]. Flavonoids functioned as good reservoirs of free radicals by protecting membrane 
lipids against damaging oxidation reactions [8] Saponin also functioned as an inhibitor of bile acid reabsorption which was synthesized from cholesterol by the intestine so that bile acids were immediately excreted with feces to overcome the loss of bile acids, cholesterol in the serum would be converted by the liver into bile acids so that there would be a decrease in cholesterol levels in the blood [9]. Polyphenols functioned as antioxidants had a beneficial effect on endothelial function by decreasing LDL oxidation and increasing nitric oxide (NO) production [5].

Empirically, fresh Jengkol leaves are usually made by boiling them and the water is drunk by the people as a medicine to reduce total blood cholesterol levels. Therefore, the writer was interested in examining the effect of ethanol extract of Jengkol (Archidendron jiringa) leaf on reducing cholesterol levels in Wistar strain male white rats fed high fat and propylthiouracil.

\section{METHOD}

A. Animals

Wistar strain male rats were tested as many as 25 individuals aged 2-3 months, with a bodyweight of 180-200 grams, each the groups consist of 5 animals.

B. Materials

Leaf of jengkol (Archidendron jiringa.), Aquadest (AprMedical $\left.{ }^{\circledR}\right)$, ethanol distillate (AprMedical $\left.{ }^{\circledR}\right)$, propylthiouracil tablets $\left(\right.$ Dexa $\left.^{\circledR}\right)$, High fat diet (used cooking oil, beef fat, quail eggs and pur 551), tween $80 \quad\left(\right.$ Brataco $\left.^{\circledR}\right)$, and simvastatin tablets $\left(\right.$ Dexa $\left.^{\circledR}\right)$.

C. Research procedure

\section{Extracting of jengkol leafs}

Jengkol leaf was cleaned from the dirty ones, washed, dried aerated, chopped into small pieces, then weighed as much as 1000 grams, then put in a dark bottle, then macerated using distillate ethanol. Immersion was carried out for 3 days with 5 repetitions. Maserat.was evaporated by vacuum distillation and thickened with a rotary evaporator

2. Treatment of Test Animals

Test animals were acclimatized for 7 days, then induced using High fat diet (PTL) and propylthiouracil (PTU) for 14 days. On the 14th day, total cholesterol levels were measured, when it was reached more than $200 \mathrm{mg} / \mathrm{dl}$ [2]. The rats were confirmed as hypercholesterolemia. The value of the measure was counted as total cholesterol levels before treatment (day 0 ). The test animals then were divided into 5 groups. The negative control group I was given $1 \%$ tween 80 . Group II was given Jengkol leaf extract with a dose of $100 \mathrm{mg} / \mathrm{kg}$ BW. Group III was given Jengkol leaf extract with a dose of 200 $\mathrm{mg} / \mathrm{kg}$ BW. Group IV was given Jengkol leaf extract at a dose of $400 \mathrm{mg} / \mathrm{kg}$. Group V as a comparison of simvastatin $10 \mathrm{mg} / \mathrm{kg}$. The study was conducted for 14 days, then cholesterol levels were measured by digitally on days 0,7 , and 14 .

3. Data Analysis

The data of the research result would be analyzed statistically using variance analysis (ANOVA) two way, continued with Duncan test

\section{R E S U L T S}

A. The extract obtained from $1 \mathrm{~kg}$ of Jengkol leaves was $75.24 \mathrm{~g}$ with a percent yield of $7.524 \% \mathrm{~b} / \mathrm{b}$. Jengkol leaf extraction by maceration for five days with three repetitions.

$B$. The results of testing the effectiveness of the delivery of blood cholesterol levels in male rats on days 0,7 , and 14 , the value of percent reduction in blood cholesterol levels of rats was influenced by each preparation and could be seen in tables 1 and 2.

Table 1. Total Cholesterol Levels Among The Group of Animals

\begin{tabular}{lccc}
\hline & \multicolumn{3}{c}{ Blood Total Cholesterol (mg/dl) } \\
\hline $\begin{array}{c}\text { Group of } \\
\text { Animals }\end{array}$ & Day 0 & Day 7 & Day 14 \\
\hline Tween 80 & $327 \pm 46,37$ & $296,4 \pm 38,59$ & $263,4 \pm 27,2$ \\
\hline $\begin{array}{l}\text { Dose of JLE } \\
\text { 100mg/kg BW }\end{array}$ & $321,6 \pm 58,74$ & $257,6 \pm 49,94$ & $187 \pm 29,29$ \\
\hline $\begin{array}{l}\text { Dose of JLE } \\
\text { 200mg/kg BW }\end{array}$ & $318,4 \pm 48,01$ & $244,8 \pm 37,65$ & $163,2 \pm 13,25$ \\
\hline $\begin{array}{l}\text { Dose of JLE } \\
400 \mathrm{mg} / \mathrm{kg} \mathrm{BW}\end{array}$ & $314,2 \pm 10,81$ & $217 \pm 8,31$ & $172,8 \pm 10,55$ \\
\hline Simvastatin & $310,2 \pm 33,43$ & $201,2 \pm 20,10$ & $123 \pm 10,84$ \\
\hline
\end{tabular}

Values are expressed as mean \pm Standard deviation of 5 rats, JLE : Jengkol leaf extract 
Table 2. Total Cholesterol Decline (\%) Among The Group of Animals

\begin{tabular}{lll}
\hline \multirow{2}{*}{ Group of Animals } & \multicolumn{2}{c}{ Total Cholesterol Decline (\%) } \\
\cline { 2 - 3 } & Day 7 & Day 14 \\
\hline Tween 80 & $9,20 \pm 1,25$ & $18,20 \pm 4,23$ \\
\hline $\begin{array}{l}\text { Dose of JLE } \\
100 \mathrm{mg} / \mathrm{kg} \mathrm{BW}\end{array}$ & $20,04 \pm 0,031$ & $41,45 \pm 0,033$ \\
\hline $\begin{array}{l}\text { Dose of JLE } \\
200 \mathrm{mg} / \mathrm{kg} \mathrm{BW}\end{array}$ & $23,17 \pm 0,021$ & $47,76 \pm 0,075$ \\
\hline $\begin{array}{l}\text { Dose of JLE } \\
400 \mathrm{mg} / \mathrm{kg} \mathrm{BW}\end{array}$ & $30,93 \pm 0,009$ & $44,91 \pm 0,041$ \\
\hline Simvastatin & $35,02 \pm 0,024$ & $56,70 \pm 0,068$ \\
\hline
\end{tabular}

Values are expressed as mean \pm Standard deviation of 5 rats, JLE : Jengkol leaf extract.

If the average percent decrease in cholesterol level above was displayed in the form of a curve, then the results obtained were shown in Figure 1:

Figure 1. Total Cholesterol Decline (\%) Among The Group of Animals on days 0, 7, 14 after the test was given.

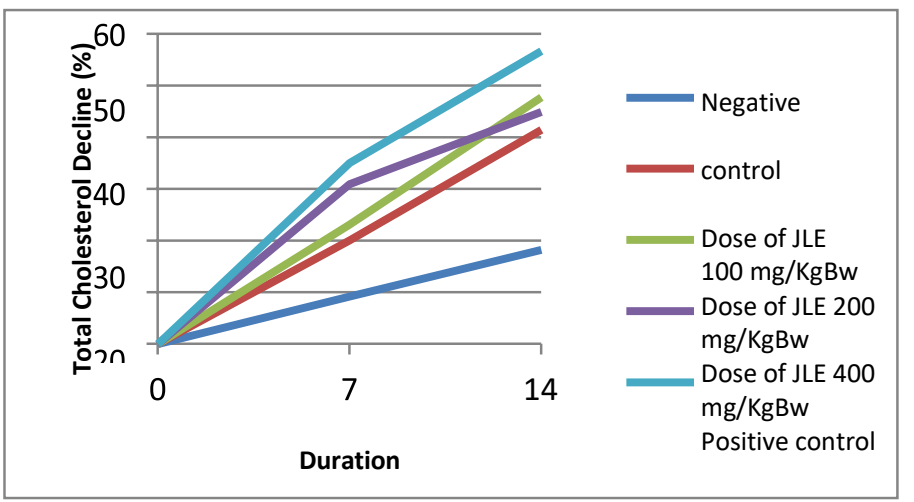

Table 3. Duncan's Test Statistical Analysis percentage of Reduction in Cholesterol Levels in the treatment group

\begin{tabular}{|c|c|c|c|c|c|}
\hline \multirow[t]{2}{*}{ Group } & \multirow[t]{2}{*}{$\mathbf{N}$} & \multicolumn{4}{|c|}{ Subset } \\
\hline & & 1 & 2 & 3 & 4 \\
\hline Tween 80 & 10 & 14,09 & & & \\
\hline $\begin{array}{l}\text { Dose of JLE } \\
100 \mathrm{mg} / \mathrm{kg} \mathrm{BW}\end{array}$ & 10 & & 30,75 & & \\
\hline $\begin{array}{l}\text { Dose of JLE } \\
200 \mathrm{mg} / \mathrm{kg} \mathrm{BW}\end{array}$ & 10 & & & 35,46 & \\
\hline $\begin{array}{l}\text { Dose of JLE } \\
400 \mathrm{mg} / \mathrm{kg} \mathrm{BW}\end{array}$ & 10 & & & 37,92 & \\
\hline Simvastatin & 10 & & & & 47,90 \\
\hline Sig. & & 1,000 & 1,000 & ,207 & 1,000 \\
\hline
\end{tabular}

Table 4. Duncan Test Statistical Analysis Percentage of Decreased Cholesterol Levels in the duration of treatment

\begin{tabular}{|c|c|c|c|c|}
\hline \multirow{2}{*}{$\begin{array}{c}\text { Duration } \\
\text { (Day) }\end{array}$} & \multirow[t]{2}{*}{$\mathrm{N}$} & \multicolumn{3}{|c|}{ Subset } \\
\hline & & 1 & 2 & 3 \\
\hline 0 & 25 & 318,28 & & \\
\hline 7 & 25 & & 243,40 & \\
\hline 14 & 25 & & & 181,88 \\
\hline Sig. & & 1,000 & 1,000 & 1,000 \\
\hline
\end{tabular}

\section{D I S C U S S I O N}

From the figure above (Figure 1), it could be seen that all treatment groups after being given the test preparations experienced an increase of percent reduction in cholesterol levels and showed a decrease in cholesterol levels for male white rats given high-fat and propylthiouracil feed.

The possible content of secondary metabolites in Jengkol leaves that played a role in reducing cholesterol levels were flavonoids and saponins [10]. Flavonoids work as an inhibitor of the enzyme HMGCoA reductase resulting in decreased cholesterol synthesis. When cholesterol is transported from the intestine to the liver, it is HMG-CoA reductase in charge of converting acetyl-CoA to mevalonate in Cholesterol synthesis will be inhibited; thus, the product cholesterol synthesis by the liver will be reduced [9]. While Arif (2012) stated saponins could also be associated with bile acids and cholesterol from food and form micelles that also could not be absorbed by the intestine. This caused the formation of cholesterol in the liver was inhibited and absorption of intestinal cholesterol was also inhibited, thus it was causing a decrease in cholesterol levels in the body [11].

In the comparison group, simvastatin had the largest percentage in reducing cholesterol levels from each treatment group namely $56.7 \%$. Simvastatin was an antihyperlipidemic drug of the oral mechanism of statins, which was the first phase of sterol biosynthesis, the active forms of structurally active reactor inhibitors analogous to $\mathrm{HMG}-\mathrm{CoA}$ intermediates formed by HMG-CoA reductase in mevalonate synthesis. This effect resulted from an increase in high-affinity LDL receptors which had an effect on increasing LDL fractional catabolic rate, as well as extraction of LDL precursors (VLDL residual) by the liver from the blood so that LDL was reduced 
and cholesterol levels had decreased [12].

On the results of normality and homogeneity obtained test data, they indicated that it had been distributed normally and homogeneously $(\mathrm{p}>0.05)$. Duncan test resulted in a $95 \%$ confidence level, the tween 80 group as a negative control significantly different from the entire treatment group, which meant that all treatment groups had antihyperlipidemic effects. In the simvastatin $10 \mathrm{mg}$, a group as a positive control had the highest percentage value of cholesterol reduction. The dose of Jengkol leave extract $400 \mathrm{mg} / \mathrm{kg} \mathrm{BW}$ did not show a significant difference with the dose of Jengkol leave extract $200 \mathrm{mg} / \mathrm{kg} \mathrm{BW}$, but the percentage value was under positive control, which meant the dose of Jengkol leave extract $200 \mathrm{mg} / \mathrm{kg}$ BW had the same effect as the dose of $400 \mathrm{mg} / \mathrm{kg} \mathrm{BW}$. From Duncan's results on the giving duration also gave a significant difference in the giving duration on days 0 , 7 , and 14 , on the 14 th day which showed the highest levels of cholesterol reduction.

The correlation test results with a $99 \%$ confidence level could be seen that there was a relationship between the treatment group to the percent decrease in cholesterol levels that is 0.351 where the relationship was included in the moderate category. Likewise, the longer the giving with the percentage decrease in cholesterol levels had a strong relationship that is 0.869 .

\section{CONCLUSION}

Jengkol leaf extract (Archidendron jiringa) affected reducing cholesterol levels in Wistar strain male white rats. Optimal dose of Jengkol leaf extract (Archidendron Jiringa) affected a decrease in cholesterol levels in male Wistar strain white rats which were induced propylthiouracil and High fat diet $200 \mathrm{mg} / \mathrm{kg} \mathrm{BW}$ with a duration of 14 days.

\section{ACKNOWLEDGMENT}

We are thankfull to Notari Bhakti Pertiwi Palembang for financial support.

\section{REFERENCES}

Anies A. Kolesterol dan penyakit jantung koroner : Solusi pencegahan dari aspek kesehatan masyarakat. Yogyakarta: Ar-Ruzz Media.; 2015.

[2] Gilman G and. Dasar Farmakologi Terapi Vol. 2. Jakarta: EGC; 2010.

[3] WHO. Global Status Report on Noncommunicable Diseases. Switzerland: 2015.

[4] Depkes. Hasil Riskesdas 2013. Jakarta: 2013.

[5] Suyatna F. Farmakologi dan Terapi. 5th ed. Jakarta:
Fakultas Kedokteran Universitas Indonesia; n.d. Karo-karo S. Cegah dan Atasi Pnyakit Jantung dan Pembuluh Darah: Karena Hidup Hanya Sekali. Jakarta: Praninta Aksara; 2016.

[7] Yunitasari D, Alifiar I, Priatna M. Uji Aktivitas Ekstrak Etanol Daun Jengkol (Pithecellobium Lobatum Benth) Terhadap Penyembuhan Luka Insisi pada Tikus Putih Jantan Galur Wistar. Jurnal Farmasi Sains dan Praktis 2016;2:30-5.

[8] Miranda C BD. Antioxidant Activities of Flavonoids. Oregon State University, 2000.

[9] Artha C, Mustika A, Sulistyawati SW. Pengaruh Ekstrak Daun Singawalang Terhadap Kadar LDL Tikus Putih Jantan Hiperkolesterolemia. EJournal Kedokt Indones 2017;5:105-9. https://doi.org/10.23886/ejki.5.7151.

[10] Harosid H. Uji Analisa Fitokimia Ekstrak Etanol dan Fraksi Air pada Daun Jengkol (Archidendron pauciflorum). STIFI BP, 2012.

[11] Hall G and. Metabolisme Kolesterol - (Fisiologi manusia). Jakarta: EGC; 2006.

[12] BG. Katzung, Master, B.S., Trevor A. Farmakologi Dasar \& Klinik. 12th ed. Jakarta: EGC; n.d. 